RESEARCH ARTICLE

\title{
International Refugees Protection in the Context of Human Rights
}

\author{
Slamet Supriadi \\ Indonesian Human Rights Networks \\ Bandung, Jawa Barat, INDONESIA \\ 的 slametsupriadi@gmail.com
}

\section{a OPEN ACCESS}

Citation: Supriadi, S. (2021). International Refugees Protection in the Context of Human Rights. Law Research Review Quarterly, 7(4), 417432.

https://doi.org/10.15294/Irrq.v $7 \mathrm{i} 4.48185$

Submitted : June 10, 2021

Revised : September 2, 2021

Accepted : November 1, 2021

(C) The Author(s)

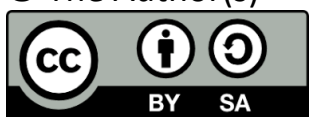

This work is licensed under a Creative Commons Attribution-ShareAlike 4.0 International License. All writings published in this journal are personal views of the authors and do not represent the views of this journal and the author's affiliated institutions.

ISSN 2716-3415

Law Research Review Quarterly published by Faculty of Law, Universitas Negeri Semarang, Indonesia. Published quarterly on February, May, August, and November.

\begin{abstract}
Refugees are defined as people who are due to a reasonable fear of persecution, caused by reasons of race, religion, nationality, membership in certain social groups and political parties, are outside their nationality and do not want protection from the country. When refugees leave their home country or residence, they leave their lives, homes, possessions, and family. The refugees cannot be protected by their home country because they are forced to leave their country. Therefore, protection and assistance to them is the responsibility of the international community. In countries receiving refugees, they often experience inhumane treatment such as rape, assault, discrimination, repatriated by force, those lead to the violation of human rights. There has been regulation for human rights in refugee issues both internationally and regionally, for instance Convention related to Status of Refugee 1951 and The Protocol related to the Status of Refugee 1967. There are at least five basic rights of refugees, they are the right to be protected from returning to the country of origin forcibly (non-refoulement), the right to seek asylum, the right to obtain equality and nondiscrimination, the right to live and to be secured, as well as the right to return home.
\end{abstract}

Keywords: International Refugees, Human Rights,

International Protection, Legal Protection, Non-

Refoulement 


\section{INTRODUCTION}

The problem of refugees and migration in the country is the most difficult problem faced by the world community today. Many discussions are being undertaken by the United Nations (UN) which continues to seek more effective ways to protect and help these highly vulnerable groups. The problem of refugees is a classic problem that often arises in the history of civilization of mankind. There are various causes that make people evacuate. These things can be caused by fear that threatens their safety (Sujatmoko, 2011; Feller, 2001; Lawand, 1996).

At first the migration of the population was only a domestic problem of a country but along with the many countries that paid attention to this issue so that it became a common problem. Refugees crossing national borders and entering a sovereign territory deserve attention because it is a universal matter. Refugees who leave their place of origin are caused by a variety of factors that are usually due to things that could endanger the lives of refugees if they are still living in their original areas such as war or persecution. They do not get protection from their own country, and often their own governments threaten to persecute them. It is equivalent to giving death decisions for them to live miserably in the shadow of life without the means of life and without any right to them, if other countries do not accept them, and not help them after entering their country.

The protection of refugees International departs from an understanding of human rights in general that every human being has the same rights and obligations. Similarly, the law regulating the treatment of refugees departs from international law on human rights. So, talking about refugees cannot be separated from the discussion of human rights (Suwardi, 2004; Wagiman, 2012; Badini, 2004).

Today the impact of the war on human rights also occurs in countries in the Middle East such as Syria, Afghanistan, Iraq, and Iran, where the residents of these countries fled to neighbouring countries and even seek 
asylum to other countries such as Australia. The example above illustrates how the impact of war in a country that neglects an important aspect of life is human rights.

Some previous studies highlighted and emphasized that the basic right is the right to security. The right is not available in their country therefore the victims want to seek refuge in another country that they consider safe and can accommodate them as refugees to continue their lives. The intended country of destination is generally a country that has ratified the refugee convention such as Australia. To reach the country they generally use sea lanes but with minimal security and knowledge of shipping and insufficient supplies (Taylor \& Rafferty-Brown, 2011; Prabandari \& Adiputera, 2019; Fiske, 2020).

Basically, each country has a responsibility to protect those in its territory, whether its citizens or foreigners who are in its sovereign territory, including those who seek refuge with refugee status or asylum seekers. The form of protection is one of them is the protection of the law in which the state is obliged to fulfil the legal rights attached to the individual law subject.

The obligation of the country of origin which is no longer able to protect the basic rights of its citizens or other countries that refuse the arrival of refugees will be taken over by the international community. The international community undertakes the necessary efforts to ensure and ensure that one's basic rights remain protected and respected. In such international protection status, a person who is in the capacity of a refugee or asylum seeker shall be protected by rights as a human being. The protection of human rights is a fundamental right in their handling. It becomes part of the obligations of the international community, on the other hand also a national obligation of a State (Sefriani, 2014; Romsan, et.al., 2003). 


\section{METHOD}

Referring to the formulation of the problem, then this research is included in the type of normative legal research, the method of legal research conducted by discussing library materials or secondary data. This legal research discusses the norm (law in the book) and uses secondary data (legal material) as the main data. Through this research, it is expected to be used to know and consider Indonesian law on the unavailability of the 1951 Geneva Conventions and the 1967 New York Protocol can be explained accurately and in depth.

Paradigm: Etymologically, the word paradigm is actually derived from the mixed word, combination from the Greek paradeigma, the meanings is next to, on the side, side by side or on edge. While deiknunai or deigma means view or show. Guba and Lincoln, in the Handbook of Qualitative Research, Paradigm is a major philosophical system, parent or umbrella, which includes certain ontologies, epistemologies and methodologies that cannot be simply exchanged, represents a certain beliefs system, which provides the way in which the world is seen, understood, and learned, in other words associating its adherents with a particular worldview.

Research Strategy: is a normative legal research and empirical / sociological law research term, FX.Adji Samekto mentions: to determine the research is normative or empirical seen from the goal to be achieved. Soetandyo Wignyosoebroto is called the doctrinal method. is a method of legal research based on rules that require that its adherence can be enforced by the use of state power (normative), acting in the world of necessities (das sollen), and the product is also religious.

Data Collection and Analysis Methods: In this legal research, the method of collecting data is done with Library Studies, the authors collect all references, reading, studying, and understand the books, describe, systematize, analyze, interpret, and assess the legislation by using legal reasoning 
related with topics raised by the author. The data obtained were analyzed qualitatively, such as the analysis performed by understanding and assembling the data collected systematically so that obtained a picture of the problem or circumstances studied. The method used to draw conclusions is the deductive method of thinking (Amiruddin, et.al., 2006).

\section{RESULT AND DISCUSSION}

\section{A. International Refugee Provisions}

The 1951 Convention and the 1967 Protocol are in principle almost identical. There are three main points which constitute the contents of the convention, namely:

1) The basic definition of refugees. The basic definition of Refugees is defined in the 1951 Convention and the 1967 Protocol is important because it is necessary to establish the status of a refugee (including refugees or not). This determination is stipulated by the country where the person is located and cooperates with the United Nations High Commissioner for Refugee (UNHCR), which handles refugee issues from the United Nations.

2) The legal status of refugees, refugee rights and duties in the country of refuge (the rights and obligations prevailing in the refugee camp are located).

3) Implementation of the agreement, especially concerning administration and diplomatic relations. Here the emphasis is on administration and diplomatic relations. Here the emphasis is on matters involving cooperation with UNHCR. Thus, UNHCR can perform its own duties and carry out supervisory duties, especially against the countries where the refugees are located. In addition to the provisions of the 1951 Convention and 1967 Protocol, international Refugees are also governed by the Organization of Africa Unity Convention and the Cartagena Declaration. The 1969 Organization of African Unity (OAU) Convention regulates the problem of refugees in the African region and has legally binding 
force for the African region. The OAU Convention further stipulates the definition of refugees, namely someone who left his country because of the external aggression, occupation, foreign domination or events seriously disturbing public order in certain parts or the whole of his country of origin or nationality. The regulation has legal implications that people who fled out of the country due to civil unrest, widespread violence and wars are entitled to claim refugee status in the territory of the host country regardless of whether they have a fear of fundamental suppression or persecution (Riyanto, 2004: 73). It was decided that certain groups of individuals who feared persecution because of civil or political status and who fled their country should be considered refugees and given a certain set of rights that set them apart from other strangers (Barutciski, 1998: 11).

Like the OAU Convention, the 1994 Cartagena Declaration also supports the Refugees' definition of the 1951 Convention. "... because their lives, safety or freedom have been threatened by generalized violence, foreign aggression, internal conflicts, massive violation of human rights or other circumstances which have seriously disturbed public order" (Riyanto, 2004: 74). Based on the above definition, in general refugees are forced to sever relations with their home country because of a fear of being grounded and experiencing persecution (persecution). This basic fear is what distinguishes refugees from other types of migrants, no matter what the situation, and from others who need humanitarian assistance. With the regulation of international refugees, refugee protection already has the force of law in international law.

The protection afforded by UNHCR begins by ensuring that refugees and asylum seekers are fulfilled their basic rights of life and are protected from refoulement (such as protection from forced repatriation to their place of origin where their lives or freedoms are in danger or 
maltreatment). In addition to protecting the basic rights of refugees, UNHCR also has the primary goal of seeking longterm solutions for refugees that will give them the opportunity to rebuild their lives in peace. Existing longterm solutions consist of local integration, voluntary repatriation, or placement in a third country (Irsan, 2007; Hamid, 2002).

Indonesia is one of the countries affected by international refugee movements, their arrival is a consequence of Indonesia's geographical condition, Indonesia is the most potential country visited by refugees and asylum seekers going to Australia by sea route8, the existence of UNHCR office in Indonesia, also become an attraction or provide opportunities for those who have the status of refugees or want to be refugees to come, trying to make their problems processable in Indonesia.9 Indonesia is also one of the countries that accept and ratify the Universal Declaration of Human Rights, Indonesia acknowledges the right to seek asylum in other countries, by ratifying the Indonesian Constitution automatically Indonesia must provide protection to the refugees entering the territory of the NKRI sovereignty.

As of 30 June 2014, there were 10,116 refugees and asylum seekers registered by UNHCR in Indonesia, of which 6,286 were asylum seekers and 3,830 were refugees. Of these, there are 7,910 men and 2,206 women. Among the refugees and registered asylum seekers, there were 2,507 children where 798 were unaccompanied children. Afghanistan, Myanmar, Sri Lanka, Pakistan, Iran, and Iraq are the principal countries of origin of refugees and asylum seekers located in Indonesia.10 For more details see Table 1 
Table 1. Data on the arrival of refugees and asylum seekers in Indonesia

\begin{tabular}{lc}
\hline Year & Number Of Refugees \\
\hline 2010 & 3.905 \\
2011 & 4.052 \\
2012 & 7.223 \\
2013 & 8.322 \\
2014 & 5.659 \\
\hline
\end{tabular}

Source: http://www.unhcr.or.id/id/unhcr-ambassador-id

These victims mostly failed to reach their destination countries and were stranded on the islands of Indonesia in extremely poor condition so that most of them had lost their lives before reaching their destination. The Government of Indonesia through the Ministry of Law and Human Rights facilitates these victims with immigration authorities who then accommodate them in immigration offices where they are stranded. Immigration cannot take immediate action to perform procedures internationally because Indonesia has not ratified the 1951 Refugee Convention and the 1967 Protocol.

Although not part of the 1951 Convention and 1967 Protocol on refugees, Indonesia must still comply with the refugee protection standards set forth in the convention, but refugees have become part of general international law, as the convention has become jus cogens. In the 1951 Convention and 1967 Protocol on Refugees, a nonrefoulement principle was adopted. "Non-refoulement is a principle in which a country should not return or expel refugees arriving in their country. Indonesia abides by the principle and accommodates the refugees and asylum seekers, although Indonesia is not the destination of the refugees. 


\section{B. The Threat of International Refugee Human Rights Violations}

The facts show that millions of children, men, and women have suffered from the exploitation of ethnic or religious conflicts of civil war. This number from year to year increased sharply, for example in the period 1992-1995 there were 180 million refugees caused by natural disasters (natural disaster). Seeing this the UN General Assembly has launched the 1990-2000 period as "the International Decade for Natural Disaster Reduction" (United Nations, 1995: 217218). Currently, refugee protection is still the reason for the existence of the United Nations High Commissioner for Refugees (UNHCR). About 26 million people in the world are concerned UNHCR. They include more than 13.2 million refugees, at least 4.7 million internally displaced persons, another 8.1 million are victims of war and returnees. The largest number came from Afghanistan (2.3 million), Rwanda (1.7 million), Bosnia and Herzegovina (1.3 million), Liberia (750,000), Iraq (630,000), Somalia $(466,000)$, Sudan $(424,000)$, Eritrea $(362,000)$, Angola $(324,000)$, and Sierra Leone (320,000) (UNHCR, 1998: 6).

Discussion of refugees will not be separated from human rights. This is reasonable because refugees are very vulnerable to inhumane treatment both in the country of origin and in the recipient country. The departure of refugees to other countries due to the circumstances is very forced and possible do not have documents. The most common treatment is torture, rape, discrimination, forced repatriation (refoulement). This explains that threats to human rights force people to cross to other countries to seek refuge. Therefore, the protection of human rights in the country of origin is very important to prevent the wave of refugees. "If the conditions of the country of origin have changed then the refugees may return to their home country or build their own community to enjoy their human rights" (UNHCR, 1998: 3). 
The protection of human rights is essential in a country. The issue of human rights violations is almost always separated from the term refugees because it is assumed that the refugees are in a state of guilt that they evacuate themselves. The current trend is the integration of human rights, humanitarian law and refugee law, as the problem of refugees now grows very complex with regard to the number, size and complexity of refugee problems limited to the post World War II approach that addresses safety and welfare issues as the greatest consideration without consider the problem of the host country as to whether it has protected the refugees or not. The essence of international human rights law regulates universal humanity without being attached to certain time and space attributes (Wagiman, 2012: 28). Human rights in the context of refugee law relate to three things: the protection of civilians in armed conflict, the general protection afforded to civilians under normal circumstances, and the protection of refugees both Internal Displaced Persons (IDP's) and transboundary refugees (Wagiman, 2012: 28).

The current global problem of refugee issues is not only the individual problem but also the problem of international relations between the home country and the host country or the asylum, therefore a law that is required not only with the legal status and protection of the refugees but includes the whole law which includes the solution and collective responsibility of all countries. It is believed to protect refugees in relation to human rights and restructuring the draft Law on Refugees, but it can also provide awareness for poor countries in ensuring the human rights of refugee issues. There are three important points that a country should take in protecting international refugees (Jacobsen, 2002: 588).

1) Increased demands on state bureaucracy to manage the population and most of the weak institutions of the state in providing assistance 
2) Increased demands on state apparatus to control and manage resources

3) The increasing demands on the state security apparatus to control the borders and security threats posed by the influx of refugees.

\section{Refugee in the Context of Human Rights}

1) Right of Return Protection to Country of Origin by Forced (Non Refoulement)

When a person or persons flee from a country of origin, a country must provide protection for its return to its home country, this is necessary to avoid further human rights abuses. For fear of persecution that could endanger his life, security and integrity. The second is to refuse the expulsion and ban of entry into a country by refugees this has been in accordance with the twin concepts in guaranteeing the right to freedom, justice, and world peace under the umbrella of human rights.

2) The right to seek asylum

After a person or group of people has been exposed to human rights violations in his country, the most he seeks is asylum. Asylum is a protection provided by the jurisdiction of a country in its territory for those who come to seek it. Asylum is needed not only to guarantee the right to life but also to prevent the occurrence of human rights violations, therefore the granting of asylum to refugees' victims of human rights violations is an important aspect in the protection of human rights, hence the granting of asylum should be considered as a principle of international law in charter of the United Nations. Granting asylum to asylum seekers in accordance with article 14 cannot be regarded as an act of hostility by other countries, especially the country of origin of asylum seekers. Asylum has been regulated in Article 14 paragraph (1) of the Universal Declaration of Human Rights namely everyone has the right to seek and enjoy in other countries asylum from persecution. The underlying principle of UNHCR is "when a large asylum 
seeker comes in, the state will at least provide temporary protection".

3) Right to Equality and Non-discrimination

Refugees have the right to be treated humanely by the country of asylum. As a general rule, the rights and freedoms recognized by international human rights law are owned by all persons including refugees entitled to respect and basic human rights as citizens of asylum country (Chimni, 2003: 15). It is crucial that the protection of human rights and freedoms of refugees globally and regionally, as it is in the foreign countries of refugees most vulnerable to discrimination. It is undeniable that IDPs usually do not carry identities or documents which can be a problem with the authorities of the country of asylum. Not infrequently, refugees are accepted in recipient countries with suspicion and lack of legal certainty of their presence in the recipient country.

4) Right to Life and Security

Refugees are the most threatened group of people in the world. Some of their basic rights are threatened during the refugee process even in their home country. At first, they feel hopeless because of loss of property, security, family and even their own life. Gil Loescher explains the refugee situation is very bad even worse than when they were in their home country, because of the compulsion to evacuate. Often refugees are separated from their family members, subject to threats, become objects of exploitation and haunted by fear of being forcibly returned to their home country. Most of the children living in refugee camps cannot live as normal as children in general. Often also refugees are at risk of getting violence including murder, rape, genocide, enforced disappearances. The most vulnerable women are victims of violence and protection against genocide which is a serious form of violation of the right to life. Because the right to life is a universal right of refugees should be protected from arbitrariness. The Vienna Declaration (1993) concerning the acknowledgment of massive human rights 
abuses in the form of genocide and systematic rape which asserted that perpetrators of this crime must be punished This declaration confirms to all countries to conduct investigations if evidence of violation of the rights of refugees by anyone. In connection with rape and sexual violence encourage all countries to implement laws protecting women including refugee women.

5) Right Back to Country of Origin

Refugees need to be guaranteed if they want to return to their home country voluntarily. In addition, refugees also need protection from force back to their home countries. Human rights regulate the right of individuals to return to their home countries The UN Security Council has confirmed "refugees and internally displaced persons are entitled to return to their home country". Refugees have the right to return to their home country and enjoy their lives. And the recipient country can return refugees if it is known in their home country that the situation is conducive, and the refugees are returned voluntarily. UNHCR and a number of other organizations responsible for the implementation of the 1951 refugee convention consistently accepted and denied the human right to return to their home country by voluntary repatriation.

\section{CONCLUSION}

Although Indonesia has not ratified the formal requirements of international refugees, Indonesia remains obliged to protect international refugees, based on the International Customary Law that on the basis of the fulfillment of Human Rights, all countries are legally binding. A comprehensive understanding of the definition and qualifications of international refugees and refugees is urgently needed, as it differs in the enforcement of human rights in terms of determining refugee status, clarity of rights and duties of internally displaced persons and asylum seekers. 


\section{DECLARATION OF CONFLICTING INTERESTS}

The Author declares that there is no potential conflict of interest in the research, authorship, and/or publication of this article.

\section{FUNDING}

None

\section{ACKNOWLEDGEMENT}

None

\section{REFERENCES}

Amiruddin, A. et al. (2006). Pengantar Metode Penelitian. Jakarta: PT. Elexmedia.

Badini, S. A. (2004). Perlindungan Hukum terhadap Pengungsi Berdasarkan Konvensi Jenewa 1951. Jakarta: Badan Pembinaan Hukum Nasional Departemen Hukum dan HAM RI.

Convention Relating to the Status of Refugees 1951 (Konvensi Pengungsi 1951)

Feller, E. (2001). The Evolution of the International Refugee Protection Regime. Washington University Journal of Law E Policy, 5(1), 129-139.

Fiske, L. (2020). Crisis and Opportunity: Women, Youth and Ethnic Minorities' Citizenship Practices During Refugee Transit in Indonesia. International Journal of Politics, Culture, and Society, 33(4), 561-573.

Hamid, S. (2002). Lembaga Suaka dalam Hukum Internasional. Jakarta: PT. Raja Grafindo Persada.

Irsan, K. (2007). Pengungsi Internal dan Hukum Hak Asasi Manusia. Jakarta: Komisi HAM.

Lawand, K. (1996). The right to return of Palestinians in international law. International Journal of Refugee Law, 8(4), 532-568.

Parthiana, I. W. (2010). Refugee and Extradition: Could a Refugee be extradited?. Indonesian Journal of International Law, 7(4).

Prabandari, A., \& Adiputera, Y. (2019). Alternative paths to refugee and asylum seeker protection in Malaysia and Indonesia. Asian and Pacific Migration Journal, 28(2), 132-154.

Romsan, A., et al. (2003). Pengantar Hukum Pengungsi Internasional. Bandung: Sanic Offset. 
Sefriani, S. (2014). Hukum Internasional Suatu Pengantar. Jakarta: RajaGrafindo Persada.

Sujatmoko, A. (2011). "Hubungan antara Hukum Humaniter Internasional, Hukum Hak Asasi Manusia Internasional, dan Hukum Pengungsi Internasional", PAPER, presented on Short Course International Humanitarian Law. Yogyakarta: ICRC.

Suwardi, S. S. (2004). Aspek Hukum Masalah Pengungsi Internasional. Indonesian Journal of International Law, 2(1).

Taylor, S., \& Rafferty-Brown, B. (2011). Difficult journeys: Accessing refugee protection in Indonesia. Monash University Law Review, 36(3), 138-161.

The Fourth Geneva Convention Relative to The Protection of Civilian Persons in Time of War 1949.

UNHCR. (1967). United Nations Declaration of Territorial Asylum 1967.

UNHCR. (2001). Perlindungan Pengungsi, Buku Petunjuk Hukum Pengungsi Internasional. Jakarta: UNHCR. 2001.

United Nations. (1967). Protocol Relating to the Status of Refugees 1967.

Wagiman, W. (2012). Hukum Pengungsi Internasional. Jakarta: Sinar Grafika. 
Refugees are not

terrorists. They

are often the first

victims of

terrorism.

António Manuel de Oliveira Guterres 